\title{
Deflecting the CNN Effect: Public Opinion Polling and
}

\section{Livingstonian Outcomes}

Lauren Kogen and Monroe Price

This is an Accepted Manuscript of an article published in Media, War \& Conflict, available online: http://dx.doi.org/10.1177/1750635211406051

\begin{abstract}
Can the analysis and dissemination of public opinion polling be organized in such a way as to shift public debate and help reframe an issue that has been strongly influenced by $\mathrm{CNN}$-like mediated activities? In this paper, drawing upon polling experience in Darfur, we look at this question in the highly disputed context of international conflicts, an area where CNN Effects are manifest. We argue that government-sponsored polls can become part of official reactions to the CNN Effect in three primary ways: first, deflecting the CNN Effect by re-framing narratives and policy options; second, trumping the CNN Effect by returning to a form of evidence-based policy making in which research, rather than media pressure, dictates decision-making; and third, circumventing the CNN Effect by engaging in improved approaches to conflict resolution.
\end{abstract}

Keywords: CNN Effect, public diplomacy, public opinion, agenda setting, surveys, conflict zones, Darfur

To cite: Kogen, L. and Price, M.E. (2011). Deflecting the CNN Effect: Public opinion polling and Livingstonian outcomes. Media, War \& Conflict, 4(2), 109-123. 


\section{Introduction}

It is difficult to discover a lacuna in the substantial literature about the $\mathrm{CNN}$ Effect, so generative a topic it has been. Here we explore one area that, we believe, has not received sufficient attention: What is the relationship between public opinion polling and the public dissemination of poll results on the one hand, and the CNN Effect on the other? In this paper, we look at this question in the highly disputed context of international conflicts, an area where CNN Effects continue to be manifest. We use as our framework and starting point for the CNN Effect Steven Livingston's (1997) trinity of political decision-making ramifications caused by media coverage of international events - agenda-setting, decision-catalyzing, and decision-impeding - and examine the relationship of government-sponsored public opinion polls to these phenomena. In this inquiry, we draw, among other current examples, on our experience seeking to design and execute a survey commissioned by the U.S. State Department, and conducted in Darfur, Sudan. In taking a critical look at our own project, we seek to begin to develop an outline of the relationship between a globally controversial subject, the media, public opinion, and the policy making process. In so doing we argue that survey efforts could be used by policy makers, among other purposes, to buffer the accelerated decision making process and agenda-setting impact the CNN Effect has been said to force.

We start with a basic observation: even if the CNN Effect has been overstated, there seem to be very real reactions by public officials to its perceived threat: that of limiting their freedom to deliberate and decide in an idealized governmental process that includes room for maneuvering. This ' $\mathrm{CNN}$ side effect' causes those charged with making and executing policy to seek (whether such seeking is necessary or not) to protect 
and preserve a space for decision-making and to shield such a space from the dynamic vagaries of media narratives that they do not control. When the CNN Effect is thought to be a threat to professionals, professionals will seek modes of alleviating it. As time has passed, as CNN Effects come and go, officials become more sophisticated in responding to, adjusting to, avoiding, or ignoring what seems to be their stunning immediacy. Immunizing or deflecting strategies multiply. They can involve bureaucratic shielding, sympathetic embracing of one of several media narratives, the launching of counter initiatives and engagement in intensely activated public diplomacy. Here we question whether one such deflecting measure could involve the adroit deployment of particular public opinion surveys.

Public opinion polls have often been cited in studies on the CNN Effect in order to corroborate the effect (see, for example, Livingston, 1997; Shaw, 1996: vii), in order to show that public opinion shifts according to, and following, media portrayals. Our point is different: we argue here that poll data dissemination can also be a part of altering the effect itself, when the dissemination of the results of polls conducted abroad changes the way publics view the issues at stake, and reshapes understandings of the context for a major foreign policy question. In so doing, polls can serve as a countermeasure to the CNN Effect for politicians and governments seeking to reclaim breathing room for decision-making, helping to provide a more commodious zone for official contemplation and action. The idea that public opinion polls are used in politics is certainly nothing new, but we show, later in this paper, in the context of Darfur, the benefits and potential dangers such a poll might offer with respect to the CNN Effect. 
Our emphasis, in this essay, is on how public opinion polls may be used in relation to the Livingstonian outcomes of agenda-setting and decision-catalyzing. We argue that the polls and the dissemination of results can become part of official reactions to the CNN Effect in three primary ways: first, deflecting the CNN Effect by re-framing narratives in the same way advocates do — to tell a particular story regarding an international conflict; second, trumping the CNN Effect by returning to a form of evidence-based policy making in which research, rather than media pressure, dictates decision-making; and third, circumventing the CNN Effect by engaging in improved approaches to conflict resolution.

\section{Public opinion polls in politics}

In the literature on politics and poll use, polls are usually either heralded as a way to integrate the public into the political sphere and allow individuals to express their thoughts on policy issues, or criticized as a way to manipulate publics or prevent politicians from making independent decisions. One of the most recognized benefits of polls to standard publics is that polls provide ordinary citizens with the means to voice their opinions regarding important issues facing the government. In the United States this role is often less marked, as there are, theoretically, multiple ways for citizens to do this, including writing to one's congressman, writing an editorial or a blog, or staging a protest. A study of U.S. and European journalists found that $40-50$ percent believe that their role in society includes giving voice to the public on current issues by acting as a mediator between the public and those in power, and that this role is "extremely 
important" (Weaver, 2008). Half believe polls help them fulfill this function (Weaver, 2008: 456).

Of course, in democratic societies, politicians often use public opinion polls as well (both those created by the government and by the media) to get a sense of what the public thinks about certain controversial issues. They can then use that information either to decide how to vote on an issue, or simply to decide how to frame their position in order to appeal to public sentiment. While it is unclear how much this information actually influences decision-making, it is generally agreed that U.S. politicians do follow public opinion data to some degree (Canes-Wrone, 2006; Jacobs \& Shapiro, 2000; Miller \& Stokes, 1963). Miller and Stokes (1963) found some correlation between voting behavior in the U.S. Congress and the opinions of congressmen's constituencies; In Canada, Page and Shapiro (1983) found that for the period between 1935 and 1979, 43 percent of political votes were in line with changes in public opinion, and in 33 percent of votes no change occurred because decisions were already in line with public opinion. They concluded that public opinion clearly moved political decisions.

Others argue, however, that politicians may use the results of public opinion polls to craft their message and spin their policy position so that it will align with, or even move, public sentiment, rather than using poll results to construct their stance outright (Canes-Wrone, 2006; Jacobs \& Shapiro, 2000), and in this way can be said to attempt to "lead" public opinion (Foyle, 2004).

Some scholars (see for example, Lijphart, 1984; Newport, 2004) advocate for more use of public opinion in decision-making, arguing that in an ideal democracy government should abide by the preferences of the public whenever possible. But others 
note the potential danger in paying too much heed to poll results. If politicians do follow public opinion polls, this can be a positive sign of a democracy for the people and by the people, but unwavering adherence to public sentiment is obviously problematic. While it is hard to say how often this is the case, we can assume that politicians are likely loathe to admitting having based an important political decision on a simplistic survey question. Such conflicting attitudes highlight the fact that while politicians may not actually vote based on a particular issue poll, they are certainly influenced by the general shifting tide of attitudes in the public, for better or for worse. The rising use of polls is, of course, related to the strengthened organic playing out of the CNN Effect as it has evolved. In aspects of the Darfur example, described below, the democratic impulse or grounding is absent. But the idea that governmental decisions are based on a better sense of public opinion is still a forceful one.

Critiques of such polls stem partially from survey questions that are often onedimensional, crudely narrowing complex policy issues into dichotomous yes/no answers, without the comprehensive context and background information the issue deserves (Herbst, 1998). This creates poll results which, in many cases, describe simply how the public "feels" about an issue, without a real sense of its policy ramifications. The distribution of such poll results to the public and to politicians can also itself manipulate opinion. Herbst (1998) notes that polls can be used opportunistically by policymakers, referenced when they support desired legislation or ignored when they do not. Gandy (2003) argues that such tactics have been used by corporations to ease privacy policy restrictions for internet advertisers. According to Gandy, the polls, sponsored by corporations, were structured in such a way as to suggest that the public did not object to 
personal data gathering, despite the fact that the public did not sufficiently understand the complexities of internet privacy policy or the issues at stake.

Traugott (2008) notes that in 1997, the organization Mothers Against Drunk Driving (MADD) used the results of a purposely leading questionnaire to (successfully) boost their case to Congress to have the legal driving blood-alcohol limit lowered. Gandy's (2003) study on privacy policy noted that the conductors of the poll argued before Congress that the poll results indicated that the audience did not oppose the "optout" option, even though the "opt-in" option (the reverse, and what was being opposed by lobbyists) did not actually appear on the surveys (Gandy, 2003: 295). These arguments, however, relate to the accuracy or validity of the survey, not the mode by which it is used for persuasive purposes.

\section{Tracing the CNN effect}

The CNN Effect, as it is has been portrayed in the scholarly literature, often takes place in a global theater-or at least a theater of influence — in which leaders and officials (usually in the developed world) are constrained or re-oriented by the impact of publicity on their domestic constituencies. In the well-rehearsed story, the term CNN Effect developed in the early 1990 s as debates developed concerning a shifting dynamic in the relationship between diffusion of news and information and official decision-making during events such as the Gulf War and the U.S. intervention in Somalia (Livingston \& Eachus, 1995). Because of the rise of CNN and the novel existence of a 24 hour news cycle specifically "at the scene," leaders began to learn more and learn first from television rather than from their own diplomats or foreign policy officials. What were 
dramatic at the birth of this named phenomenon were the apparent innovative qualities of televised battling for dominance and their seemingly startling and impressive consequences for diplomacy. Even the new name of CNN's news center-the Situation Room — captured this idea that the locus of decision-making had allegedly shifted from an official site to a mediated one.

Leaders began to conduct diplomacy in real time and in the fishbowl of a global news service. The elaborate and choreographed ceremony and bureaucracy of diplomacy seemed to be diminishing. Traditional asymmetries of power seemed to be in rapid decline as television-legitimated leaders could acquire screen time, directly reach past official and autocratic gatekeepers and speak both to previously protected major officials as well as to broad civil publics. Official reaction time had to be accelerated. The CNN Effect became part of a toolkit of effective persuasion, not only for field rebels and for leaders who might otherwise have been neglected, but also for many non-state players, celebrity figures, NGOs, and others who learned to look at media as vehicles to alter public opinion and constrain, shape, or influence the policy responses of public officials.

In the two decades since, some scholars and politicians have doubted the strength of the CNN Effect, questioning first whether or how it was ever a significant force. Livingston (1997) breaks down the phenomenon by explaining that what was referred to as the CNN Effect was more accurately a concatenation of three inter-related effects of the media on political decision-making that came together following the end of the Cold War, at a time when the U.S. government was particularly vulnerable: media as agendasetter, as decision-catalyzer, and as decision-impeder. As agenda-setter, the media in certain cases dictate which international humanitarian efforts will become political 
priorities, by choosing which stories to cover, and covering them in a way that produces sympathy among viewers. As decision-catalyzer, the media take away the period of time that was previously available to decision-makers to reflect on the situation, conduct research, and weigh various policy options. This, according to Livingston, forces decision-makers to decide on policies almost as soon as they emerge on the public agenda, "sometimes dangerously so" (1997: 2). As decision-impeder, the media can either turn public opinion against a particular policy decision, or threaten military success and security when details of particular operations are revealed.

Like militaries seeking to adapt when those they face find new weaponry, diplomats and governments predictably seek to adjust to an altered media world. Many of those who seek to shape foreign policy or react to it have internalized the phenomena of global news services and the CNN Effect and have modified their behavior accordingly. Once governments saw the impact of the CNN Effect, once they could more consciously calibrate the consequences of various appearances on global news channels, the transformative impact of the new technology was lessened. In the next section we explore the ability of government-sponsored public opinion polls to shield officials from the phenomenon.

\section{Re-framing and evidence-based decision-making efforts in other contexts}

Darfur was selected as a focus for our study largely because of its status as a contemporary example of the CNN Effect and our own experience in fashioning the use of public opinion polling there as an aid to public decision-making. But Darfur is not the only case, and so we shall place Darfur in the context of two other cases - Iraq and 
Afghanistan - which also serve as examples where public opinion polls have been deployed, arguably, to maintain options for policymakers in the United States. In Iraq, polls conducted since 2003, both government and privately funded, have dealt with a key argument of those seeking to shape U.S. policy: that Iraqis wanted immediate withdrawal or, put differently, that they did not want foreign troops in the country (Gagliardone \& Stremlau, 2008). These polls, even those conducted at approximately the same time, reported vastly different results. For example, one survey at least partially funded by the Coalition Provisional Authority (CPA), and reported by the BBC, found that only 15 percent of Iraqis thought U.S. troops should leave "immediately" (BBC, 2004). Another survey conducted around the same time, funded by USA Today, CNN, and Gallup, and reported in USA Today, found that 57 percent of Iraqis thought troops should leave immediately (Soriano \& Komarow, 2004).

In the case of Afghanistan, the U.S. government has encouraged the reporting of polls among the Afghani people (some conducted with U.S. government funding) that could be interpreted as evidence that the affected population considered the U.S. intervention as having a positive effect. Some polls highlighted the relatively optimistic outlook of Afghanis. A typical report—during a critical period for gaining support for U.S. policy—read: "Hopes of a brighter future have soared in Afghanistan, bolstered by a broad rally in support for the country's re-elected president, improved development efforts, and economic gains. Blame on the United States and NATO for violence has eased...” (Langer, 2010).

The range of results in the Iraq case, and the optimistic tone in the case of Afghanistan, show that there is at least a potential for policymakers to selectively use 
polls to argue for particular policy choices. While we are not making the case that the groups which developed or funded these polls intentionally sought a particular narrative, it is certainly likely that these results could impact audiences, not only politicians, and that a public belief that Iraqis wanted American troops to stay, or that Afghanis were mildly approving of U.S. actions, could cool hostility toward U.S. government intervention policies.

These are examples of how the CNN Effect might be both deflected and trumped by U.S. officials in cases of international interventions when poll results allow the data to fit a particular narrative. Several scholars have documented the so-called "bandwagon" or momentum effects, when the very knowledge that a particular opinion is popular leads a greater portion of the public to take on that opinion (Marsh, 1984; Mutz, 1997) or the theory of "impersonal influence" which "derives from individuals' perceptions of others' attitudes, beliefs, or experiences" (Mutz, 1992). This type of re-framing for the purposes of moving public sentiment echoes the techniques used by policy advocates, and offers a possibility of CNN-effect deflection for policy makers. In addition, these Iraqi and Afghan examples present concrete research regarding what strategies should be pursued, meaning that these types of polls offer another way to defend against the CNN Effect by favoring evidence-based forms of decision-making which rely on collecting concrete data on the ground rather than influencing the attitudes of Americans exclusively through psychological phenomena. In this way, a space for deliberation is created by claiming adherence to numbers, rather than the pressures of celebrities and advocacy groups. In the next section we will see how these same conditions could apply in Darfur. 


\section{Darfur as a Case Study}

We turn to our experience with survey work in Darfur as a way of thinking about the potential relationship of polling to the CNN Effect. Because of preexisting work on the relationship between communications, media and violence, we received a contract from the U.S. Department of State to design and conduct a public opinion survey effort in Darfur. Our task was hardly to cope with CNN Effects, either to augment them or deflect them. Indeed, the circumstances of conducting or trying to conduct a public opinion survey in Darfur were so daunting and complex that merely surviving and performing proved to be a near insurmountable task. Yet the experience of engaging in this work provides useful insights into new ways of thinking about CNN Effects and their relationship with polling, and it is these insights we seek to reflect upon here.

It is virtually impossible to determine what range of impulses motivates governments or other parties to undertake public opinion surveys: when they are designed to elicit information and when, among other things, they are part of a combination of efforts to affect the public agenda. In the case of our opinion survey in Darfur, however, because we have more familiarity with the process, we can engage in a "thought experiment." We take our own complex experience in helping to design and implement a public opinion survey in Darfur and ask how that very difficult experience could cast light on future efforts that might link polling abroad to moderation of a CNN Effect. This process might demonstrate how those engaged in the shaping of foreign policy might or might not be able, in CNN Effect circumstances, to deploy surveys and their dissemination as an additional or counter-framing tool, or, as well, a method of altering the media's agenda-setting or decision-catalyzing abilities. Through this experiment, we 
can see not only how a survey like ours might have been used for a CNN Effect-type deflection through re-framing efforts, but perhaps more importantly, how public opinion polling in the case of conflict regions can be used in an attempt to return to a form of evidence-based research, or as a way to improve approaches to conflict resolution.

By underscoring the contrast among methods and uses of such polling efforts, we put into relief the interplay between specific designs of public opinion surveys and the CNN Effect. The point is not to offer a toolkit for manipulating public agendas, but to try to understand the dynamic that might exist as public officials seek to navigate in an environment where audiences are being strongly influenced through a variety of communications approaches.

Our involvement in Darfur was first associated with efforts aimed at providing greater understanding, among Darfurians, of the then-recently drafted Darfur Peace Agreement (in the period before the acknowledged failure of the DPA). The African Union sought to distribute information about the DPA, particularly in refugee camps. Public opinion polling was considered as a way of testing whether improvised methods, used in the absence of conventional media in the region, were adequate to inform Darfurians in a way that might prove a basis for informed acceptance.

After the DPA was substantially abandoned as a basis for moving forward, this function of polling no longer held. As impasses in the negotiations became more embedded, searches for alternative ways of approaching questions became more salient, especially in the heightened, mediated glare of attention. It was in the context of these failed peace negotiations, and the emergence of multiple factions of the movements, that our project took place. 


\section{Darfur and the CNN Effect}

There can be little question that the Darfur conflict was an example of the CNN Effect — in its more recent embodiment — in action. There was a concerted effortsymbolized by the work of the NGO Save Darfur - to use media opportunities (coupled with research and mobilization) to affect the agenda of the State Department, to hasten intervention and to impede alternative approaches. The literature on Save Darfur and its interaction with government is extensive (Crilly 2010a; Flint, 2010; Lanz, 2009; Mamdani, 2009). Darfur-like many conflict-related disputes of international significance - featured efforts at agenda-setting and other elements of the Livingston canon. In efforts by advocates and celebrities involved to force political action, framing of the dispute by advocacy groups as genocidal was a central argument. ${ }^{1}$ If Darfur could be classified as a "genocide," then the flexibility of response of signatories to the Genocide Convention under international law was narrow. Almost from the outset in 2003, many groups and governments articulated the dispute as genocidal in the media, pressuring the government to act, and in some cases pressing for military intervention. Many international civil society and humanitarian organizations reinforced rebel groups in seeking to fix the agenda on the global consciousness. George Clooney, a member of the Save Darfur coalition, addressed the UN Security Council in September 2006, excoriating its members for their lack of action on the conflict: "My job is to come here and... speak on behalf of the millions of people who will die - and make no mistake, they will die - for you to take real and effective measures to put an end to this... It's not getting better. It's getting much, much worse... How you deal with it will be your legacy, your Rwanda, your Cambodia, your Auschwitz" (qtd. in Mamdani, 2009: 54). The 
emphasis by Save Darfur and others was on shaping the world's understanding of the conflict as a genocide by the Arab government and government-funded Arab janjaweed militias upon Africans in Darfur.

In Livingston's terms, such strategies could therefore be considered both agendasetting and decision-catalyzing in that the aim was to force international governments to intervene to end the violence by defining the event as one of clear Treaty violation and genocide. Huge movements were fostered to engage in shaping public opinion on these questions with the aspiration that Livingston's agenda-setting and catalyzing effects would occur, that there would be greater compulsion to adopt certain punitive steps, and adopt them quickly. Thus, how the conflict was framed had concrete implications for U.S. policy if the United States did not want to be seen as taking genocide lightly. It had implications in terms of military actions, sanctions, U.S. support for the International Criminal Court (ICC), and relations with China.

How Save Darfur functioned and how it, and others, framed the history of conflict, was the subject of vigorous global debate and an epic illustration of Livingstonian outcomes. Crilly (2010a), a critic of Save Darfur, argued that the extreme pressure for action on Darfur may have actually fuelled the conflict, because steps were taken before a clear assessment of the violence and the power dynamics involved were made. De Waal (cited in Jansen, 2010) likewise argued that the decision to send thousands of UN troops to an area of which the West had little practical information was an irresponsible, dangerous, and hasty decision. Mamdani (2009) laid much of the blame for uninformed action at the feet of Save Darfur as well. According to Mamdani, NGOs on the ground called Save Darfur "irresponsible" and "[un]informed by the realities on 
the ground," and wholly disagreed with the group's proposal for a no-fly zone in Darfur that they argued would "endanger the lives of both aid workers and their IDP aid recipients" (2009: 50). Mamdani accused Clooney of being insufficiently concerned with accuracy in that 1) the death toll, even by the highest estimates, was not more than 400,000 at the time, and 2) by the time Clooney made this statement, the conflict was not getting "much, much worse," but had actually seen the death rate fall below levels usually associated with humanitarian emergencies (Mamdani, 2009: 55). The purpose here is not to determine whether Save Darfur and the celebrity efforts had it right, but to show that there were several deeply competing ways of presenting the narrative, each of which provided a logical foundation for different arguments regarding resolution - some of which veered more sharply than others from American policy in Sudan at that time.

\section{Public opinion polling in Darfur}

The State Department in 2008 issued a tender for survey research in Darfur. It is impossible wholly to establish motivation for a tender, but this request seemed based on the notion that it was vital for State and other actors to understand better the position of Darfurians themselves. The hope was that this knowledge would inform policy decisions regarding conflict resolution, possibly renewing a stalled political process. This chain of reasoning - underpinning the potential importance of public opinion surveys — was dependent on several assumptions: i.e. that failure of the DPA was partly attributable to a lack of ownership by Darfurians; that the DPA as it then stood was not generally supported by Darfurians; that few members of what might be called Darfuri civil society, including Darfuri religious or tribal leaders or nomadic Arabs had attended the peace 
negotiations which led to the DPA; and that, as a result, the DPA lacked legitimacy. The State Department made two awards: one to our group and one to 24 Hours for Darfur. Our survey would sample opinion among groups in the towns and refugee camps in Darfur (and nomads - about which more later) to determine the views of those not necessarily represented in most deliberations about Darfur's future. The 24 Hours for Darfur survey would cover the refugee camps in Chad.

When the State Department issued its request for tenders, it sought modes of finding answers to the following questions:

1. How do people in Darfur understand the conflict, its roots, and current events?

2. How do Darfurians feel about current and past peace processes in Darfur, including the Darfur Peace Agreement, the UN/AU peace process, and the Sudan People's Initiative?

3. How do Darfurians view Darfuri and Sudanese political and traditional leadership and the Darfuri movements?

4. What are Darfuri attitudes about peace, justice, and reconciliation in Darfur?

5. What role do Darfurians see for themselves in the 2009 Elections and in democratization in Sudan more generally?

Thus framed, the public opinion research was to provide insights into what Darfurians on the ground thought of the positions articulated by various actors, who they felt most represented by, and which issues they valued most in bringing peace to Darfur. Answers to these questions were thought crucial not only for learning ways to bring an end to the conflict, but for understanding the discrepancies between the views of the West and those of the victims of the conflict. 


\section{$\underline{\text { Possibilities for re-framing and evidence-based decision-making }}$}

The questions that appeared in the request for tenders did not highlight or confront elements of the debate as it had been set forth in the most fervent advocacy perspectives, i.e. whether or not the events in Darfur had been genocidal or whether or not the President of Sudan should be indicted before the International Criminal Court. Nor did they specifically address the role of the United States or other international players in the process, for example the role of China or international trade or economic policy. Instead, the survey explored what Darfurians considered to be the key issues at stake. Specifically, the focus was internal, on Darfurians themselves and their own role in the conflict and its peaceful resolution. Indeed, in the extensive initial period of the project, time was spent in Sudan to learn how Darfurians on the ground saw the situation so that better formulation of the survey could ensue. ${ }^{2}$

A pilot survey was conducted in December 2009. Results indicated that the distribution of power in government was an important issue for respondents. A significant proportion of participants wanted tribal, religious, and native administration leaders to be included at some level in future peace negotiations. Most of the respondents viewed Darfuri inclusion in decision-making positions at local and national levels as important or very important.

The results also indicated that the Sudanese National Government and the ruling National Congress Party (NCP) had high levels of support among some groups, and that these entities might be perceived to be trustworthy in stopping the violence and improving the security situation. Many Darfurians had mixed opinions regarding the rebel groups. The data showed that rebels may not be trusted to reduce violence, but at 
the same time indicated that there may be a role for them in the peace process and perhaps in the government in the future. There was also evidence that there is a role for the West that is not necessarily a military one. Many of the Darfurians we interviewed believed the international community should provide funds for compensation, but that their role in providing security should be limited.

Finally, we also found that while Darfurians wanted greater respect for human rights, and equality and human rights education in schools, there did not seem to be substantial interest in a Truth and Reconciliation Commission, which may suggest that changes in local governance procedures are considered by Darfurians to be more important than "justice" as defined by the West and the International Criminal Court (ICC).

All of these results offer potential for CNN Effect deflection by re-framing the narrative in ways which would support alternative political responses. Because the project is still ongoing, it is not yet possible to trace the impact of dissemination of its conclusions. But our point relates to Darfur as a case study: diffusion of the results (or selected results) to Western audiences - i.e. their distribution into the public realm—has the potential to deflect agenda-setting strategies by presenting an argument for a political response very different from those being advocated by other groups. In that sense, the survey has similarities to the Iraq and Afghan poll efforts described above in that the results could be possibly productive of an alternative framing of the dispute and offer alternative mechanisms for dealing with the conflict. The results could also reinforce or diminish the assertions that had generally been made at the time that public consciousness was being formed, and so possibly alter the degree of direction of the 
alternatives policy makers might claim. In addition, as in the Iraq and Afghan examples above, the second CNN Effect defense - a return to a form of evidence-based decisionmaking based on measurable data - goes hand-in-hand with the first. Decisions based on these results could be argued to trump the Effect because they are based on a highly relevant source: the opinions of those being directly affected by the conflict. By seeking evidence-based foundations for policy making the poll illustrates the potential for providing policymakers a space of respite — whether desirable or not—from prevailing external efforts to shape public attitudes in the United States and the West generally.

\section{$\underline{\text { Possibilities for improved conflict resolution strategies }}$}

The preceding paragraphs suggest how the State Department, or any decisionmaking body, might have conceptualized the purpose of such a poll, or disseminated such poll results strategically to various publics, to buffer the impact of the CNN Effect. However, the research team, with the support of the State Department, determined that a more useful audience for the poll results were those who would be deeply involved in peace negotiations (including, but not exclusively, officials).

From the start of the project, a key purpose of the survey had been to provide a way for Darfurians to be represented at the peace talks - if not in person, then at least by proxy, through a survey that could claim it fairly and impartially represented Darfuri opinion on specific measures outlined in the agreement, on the roots of the conflict, and on levels of trust attributed to peace negotiation participants. While it was argued that the rebel groups represented the interests of the Darfurians, and their presence alone at the 
negotiations was sufficient, this contention diminished in influence because of the dissolution of the pre-ordained representatives into splinter groups.

Indeed, one outcome of the failed DPA negotiations has been the gradual emergence of what might be called the equivalent of civil society groups demanding greater participation. As the exclusion of such groups came to be seen as one of the failings of the DPA, the survey needed to begin to correct this imbalance. For this reason, our research group shifted, before the pilot survey took place, to include a "Peace Polling" perspective in addition to the focus on the State Department questions. In July 2009, Colin Irwin joined the team, and his model of questionnaire design, intended specifically for conflict situations, was implemented. The philosophy of Irwin's peace polls (Irwin, 2001) is that rigorous public opinion research can shortcut some complexities of negotiation and test key issues directly with the people who would personally experience the viability of a peace agreement. Under this methodology, adversarial stakeholders need to be included in the question development as well, so that common issues can be identified. In addition to increasing the utility of the results, the transparency of the consultative process aims to build trust amongst the parties and trust in the research findings. Thus, in addition to including African victims of the conflict, civil society members, local elites, religious leaders, and academics, the team also decided that the survey should not go forth without including the Government of Sudan (GoS), the nomadic Arab tribes of Darfur, and rebel group leaders. In the case of GoS, this was partly a practical issue, in that the research team would have had difficulty conducting a survey in Darfur without its approval. More significantly the GoS represents 
a key voice in negotiations, and to ignore their interests in the survey design would have been inconsistent with the peace polling philosophy.

Among other things, this approach meant a radically different relationship to CNN Effect interactions. Peace polling designed to influence negotiators would, for the most part, be properly addressed to the negotiators themselves, not to a larger audience. This shift would represent an alternate detour from the CNN Effect: distribution of poll results to an American audience, at least in the mainstream media, would become unlikely, given the specificity of the questions asked and the level of knowledge required to respond. It is unlikely that, say, questions regarding oversight of the native administration in Darfur would become strong movers of public sentiment in the West, where these topics are generally not covered in the media. In other words, by moving to an assumption that public opinion polling and strategic dissemination of the results would give previously disregarded stakeholders in Darfur the perception that they were represented in the negotiations, a different "public" was both the subject and the target. We were aiming the results at two specific audiences: the Darfuri public, which would check claims of various participants (rebel groups, for example, or claims of those representing the state), and peace negotiation stakeholders (mainly GoS and rebel group leaders) in hopes that knowledge of what Darfurians actually wanted would influence the peace agreement they would agree to. And finally, grounding decision-making on public opinion findings might give the ultimate outcome of negotiations more legitimacy.

Another strategic shift in the survey design involved the inclusion of nomadic Arabs. The nomadic Arabs of Darfur make up approximately one third of the Darfuri population. Because of laws restricting their migration routes, they have been directly 
involved in many of the land disputes in Darfur which have contributed to the conflict. Despite this, the group has thus far been largely left out of the peace negotiations and had been seen more as an element of the government-backed janjaweed militias than as a major element of the local definition of populations of Darfur. Media framing of the conflict is often presented in the West as one between African "victims" and Arab "perpetrators" even though only a small portion of nomadic Arabs are part of the janjaweed and most nomads consider themselves victims of the conflict as well (Crilly, 2010b; Mamdani, 2009). Because of their typical characterization as perpetrators, and because of the practical difficulties of surveying a nomadic population, this group was left out of the sampling design when it was shaped under the first set of State Department questions. But it was later decided, when the negotiations were the focus, that leaving out this group would severely weaken the results and effectiveness of the project.

\section{Conclusion: Public Opinion Polls and Policy Making}

What are potential lessons learned from the Darfur polling efforts about the relationship between such surveys and the CNN Effect? We describe this in terms of two Livingstonian aspects of the phenomenon: agenda setting and decision-catalyzing. We are far from arguing that public opinion polls in conflict zones are always or specifically designed to respond to media-created narratives, but both of these effects could feasibly be moderated through the use of public opinion polling. Public opinion polling can be used to increase evidence-based decision-making, to reframe public debate, and to explore and encourage alternative strategies. 
In the case of Darfur, seeking out opinions of Darfurians themselves could give stakeholders the chance to both re-frame popular narratives by emphasizing different issues as key to resolution (thereby deflecting agenda-setting efforts by other players), and eschew decision-catalyzing efforts in favor of a return to evidence-based decisionmaking (thereby giving government the space to form their own policy course).

Widely diffused reports of answers, after a survey was complete, might function as part of a meaningful public dialogue on an agenda for Darfur. The actual survey did not directly connect to the basic public narrative of genocide or ICC indictment. But the raising of new understandings of Darfuri preferences carried the potential for shifting the debate. Public opinion polling, if persuasively put forward as a way of signifying participation by a designate public, could be a response to efforts to catalyze by suggesting additional procedural steps that needed to be taken before governments committed to a particular strategy.

A third use of public opinion polling is to reenergize stalled peace negotiations. In the case of Darfur polls offer the possibility of providing surrogate representation to marginal groups at the bargaining table, providing a check against claims as to the salience of demands that are made by opposing parties, and testing how representative various claimants are to authority. In this case the survey is useful not only in its results, which can be circulated to those present in peace discussions, but also in the process of data collection itself, when those directly affected by the conflict can be active participants in conflict resolution by voicing their opinions. In this sense, polling can also be a mode of CNN Effect circumvention-circumvention of the decision-forcing elements of the CNN Effects process - by refocusing the target audience from the 
American public to local citizens, civil society, and other stakeholders in the conflict, and collecting data with the goal of pinpointing areas with greater potential for conflict resolution.

The "CNN Effect" - in these multiple senses - becomes part of a process of competing efforts to command the narrative or function with partial immunity from a mediated onslaught. There are extraordinary democratic and participatory benefits for the use of the media to take the debate out of closed diplomatic precincts. But when the mediated narrative begins to dominate, public officials (and competing stakeholders) seek counterefforts to modulate the impact. Public opinion polls, we have tried to show, can, in some circumstances, do various parts of this work.

\footnotetext{
${ }^{1}$ Related was a focus on an indictment of Sudan's President before the International Criminal Court.

${ }^{2}$ The first period of the project involved numerous interviews and discussions with local NGOs, civil society groups, local elites, religious leaders, and academics at the University of Zalingei Peace Center in West Darfur, the Medina Center in South Darfur, and the University of El Fasher Peace Center in North Darfur. Extensive interviews with IDPs were conducted in the camps, including Mornie, Zalingie, Kass, Nyala, Marla, Wadi Saleh, Beida (on the border with Chad), Katula, and Ad-Da'ein. This resulted in the development of local networks and pockets of expertise for taking the project forward, which included an enhanced awareness of how to carry out research in conflict zones in general and in Darfur in particular.
} 


\section{Works Cited}

BBC. (2004) ‘Survey Finds Hope in Occupied Iraq', URL (consulted April, 2010): http://news.bbc.co.uk/2/hi/middle_east/3514504.stm

Canes-Wrone, B. (2006) Who Leads Whom? Presidents, Policy and the Public. Chicago: University of Chicago Press.

Crilly, R. (2010a) Saving Darfur: Everyone's Favourite African War. London: Reportage Press.

--- (2010b, March 16) 'Vilified Arabs of Darfur Must be Included in Peace Process', Irish Times Online, URL (consulted May, 2010):

http://www.irishtimes.com/newspaper/world/ 2010/0316/1224266351081.html

Fan, D. P. (1988) Predictions of Public Opinion from the Mass Media: Content Analysis and Mathematical Modeling. Westport, CT: Greenwood Press.

Flint, J. (2010) 'Rhetoric and Reality: The Failure to Resolve the Darfur Conflict', HSBA Working Paper 19. Geneva, Switzerland: Small Arms Survey, Graduate Institute of International and Development Studies.

Foyle, D.C. (2004) 'Leading the Public to War? The Influence of American Public Opinion on the Bush Administration's Decision to Go to War in Iraq', International Journal of Public Opinion Research 16(3): 269-294.

Gagliardone, I. and N. Stremlau (2008) 'Public Opinion Research in a Conflict Zone: Grassroots Diplomacy in Darfur' International Journal of Communication 2: 10851113. 
Gandy, O. H. (2003) 'Public Opinion Surveys and the Formation of Privacy Policy' Journal of Social Issues 59(2): 283-299.

Grim, R. (2010, January 13) 'Experts on Afghanistan Doubt Survey on Foreign Occupation: Results are Impossible', Huffington Post, URL (consulted March, 2010): from http://www.huffingtonpost. com/2010/01/13/afghanistan-expertsdoubt_n_422482.html

Herbst, S. (1998) Reading Public Opinion. Chicago: University of Chicago Press.

Irwin, C. (2001) 'How Public Opinion Polls Were Used in Support of the Northern Ireland Peace Process', The Global Review of Ethnopolitics 1(1): 62-73.

Jacobs, L. R. and R.Y. Shapiro (2000) Politicians Don't Pander: Political Manipulation and the Loss of Democratic Responsiveness. Chicago: University of Chicago Press.

Jansen, A. (2010) 'The Ethic of Refusal: (Or) the Inability to Cope with Powerlessness in the Face of Human Tragedy', Social Science Research Council Blogs, URL (consulted May, 2010): http://blogs.ssrc.org/sudan/2010/02/19/the-ethic-of-refusal/

Langer, G. (2010, January 11) 'Views Improve Sharply in Afghanistan, Though Criticisms of the U.S. Stay High', ABC News Online, URL (consulted May, 2010): http://abcnews.go.com/ PollingUnit/afghanistan-abc-news-national-survey-pollshow-support/story?id=9511961

Lanz, D. (2009) ‘Save Darfur: A Movement and its Discontents', African Affairs, URL (consulted June, 2010): http://afraf.oxfordjournals.org/cgi/reprint/adp061v1 Lijphart, A. (1984) Democracies: Patterns of Majoritarian and Consensus Government in Twenty-One Countries. New Haven, London: Yale University Press. 
Livingston, S. (1997) 'Clarifying the CNN Effect: An Examination of Media Effects According to Type of Military Intervention', Policy Paper No. R-18. Cambridge, MA: The Joan Shorenstein Center, Havard University John F. Kennedy School of Government.

Livingston, S. and T. Eachus (1995) 'Humanitarian Crises and U.S. Foreign Policy: Somalia and the CNN Effect Reconsidered', Political Communication 12(4): 413429.

Mamdani, M. (2009). Saviors and Survivors: Darfur, Politics, and the War on Terror. New York: Pantheon.

Marsh, C. (1985) 'Back on the Bandwagon: The Effect of Opinion Polls on Public Opinion', British Journal of Political Science 15(1): 51-74.

Miller, W. and D.E. Stokes (1963), 'Constituency Influence in Congress', American Political Science Review 57(1): 45-56.

Mutz, D.C. (1992) ‘Impersonal Influence: Effects of Representations of Public Opinion on Political Attitudes', Political Behavior 14(2): 89-122.

--- (1997) 'Mechanisms of Momentum: Does Thinking Make It So?', The Journal of Politics 59(1): 104-125.

Newport, F. (2004) Polling Matters: Why Leaders Must Listen to the Wisdom of the People. New York: Warner Books.

Page, B. I. and R.Y. Shapiro (1983), 'The Roles of Public Opinion Research in Canadian Government', American Political Science Review 77(1): 175-190.

Shaw, M. (1996). Civil Society and Media in Global Crises. London: Pinter. 
Soriano, C. G. and S. Komarow (2004, April 29) 'Polls Find Optimism about What Lies Ahead', USA Today, URL (consulted May, 2010):

http://www.usatoday.com/news/world/iraq/2004-04-29-iraq-poll_x.htm

Traugott, M. W. (2008) 'The Uses and Misuses of Polls', in W. Donsbach and M. W.

Traugott (eds) The Sage Handbook of Public Opinion Research, pp. 232-239.

London: Sage publications.

Weaver, D. H. (2008) ‘Attitudes of Journalists toward Public Opinion Research', in W.

Donsbach and M. W. Traugott (eds) The Sage Handbook of Public Opinion

Research, pp. 451-458. London: Sage publications. 